\title{
Comparing Domain-specific Physical Activity Efficacy Level between Turkish Adolescent Girls and Boys
}

\author{
Fatih Çatikkaş \\ Correspondence: Fatih Çatikkaş, Manisa Celal Bayar University Sport Sciences Faculty, Turkey. \\ Received: June 14, 2017 \\ doi:10.11114/jets.v5i8.2492 \\ Online Published: July 12, 2017 \\ URL: https://doi.org/10.11114/jets.v5i8.2492
}

\begin{abstract}
The adolescence period is a very critical developmental period for personality, socializing and promotion of physical activity. In this regard, the aim of this study was to compare domain-specific physical activity efficacy level between adolescent boys and girls. A total of 219 girls (body weight: $57.50 \pm 10.44 \mathrm{~kg}$, height: $160.30 \pm 7.40 \mathrm{~cm}$, age $16.15 \pm 0.96$ years) and 145 high school boys (body weight: $63.45 \pm 10.10 \mathrm{~kg}$, height: $173.71 \pm 5.49 \mathrm{~cm}$, age $16.20 \pm 3.49$ ) participated in this study. Physical activity efficacy level was evaluated by the Domain Specific Physical Activity Efficacy Questionnaire (DSPAEQ) which was adapted into Turkish by Saygin et al. (2017). Statistical analysis has shown DSPAEQ score differences between girls and boys $(\mathrm{p}<0.05)$. Scores for the school activity $(\mathrm{p}<0.05)$, transportation activity $(\mathrm{p}<0.05)$ and leisure activity $(\mathrm{p}<0.05)$ sub-dimensions were higher in boys than in girls. However, the household activity sub-dimension score was higher in girls than in boys $(p<0.05)$. The results from this study indicated that adolescent girls should be encouraged towards more physical activity both at school and out of school. However, comprehensive studies with larger samples are needed for a better understanding of the participation of adolescents in physical activity.
\end{abstract}

Keywords: adolescent girls, adolescent boys, domain-specific physical activity efficacy

\section{Introduction}

One of the major health problems of the 21st century related to public health is physical inactivity (Blair, 2009). Physical inactivity leads to premature deaths, chronic diseases such as cardiovascular diseases, diabetes, obesity, high blood pressure, osteoporosis, lipid disorders, depression, and anxiety, and physical inactivity also increases the risk of colon cancer (http://www.who.int/mediacentre/news/releases/release23/en/ Retrieved: 10.06.2017).

Approximately 3.2 million deaths each year are attributable to insufficient physical activity (http://www.who.int/dietphysicalactivity/factsheet_inactivity/en/ Retrieved: 10.06.2017). Oldridge (2008) reported that in developed countries, physical inactivity accounts for $1.5 \%-3.0 \%$ of total direct healthcare costs. The direct cost due to physical inactivity represented $2.4 \%$ of total healthcare costs in USA, $1.5 \%$ in UK and $7.4 \%$ in Czech Republic (Kruk, 2014).

A position stand released by the American College of Sports Medicine (ACSM) recommended energy expenditure of approximately $1000 \mathrm{kcal} \cdot \mathrm{wk}^{-1}$ of moderate-intensity physical activity (or about $150 \mathrm{~min} \cdot \mathrm{wk}^{-1}$ ), which is associated with lower rates of CVD and premature mortality (Garber et al., 2011).

Some authors have shown that physical activity during leisure is associated with a decrease in all-cause mortality and may extend life by 1-2 years (Pekkanen et al., 1987; Paffenbarger et al., 1986).

Al Snih et al. (2002) and Artero et al. (2011) suggested that low muscular strength in adulthood predicts all-cause mortality and mortality due to cardiovascular disease and cancer in healthy people and those with diseases.

In this regard, screening for physical activity levels of middle-aged and young people is highly important in preventing disability, morbidity, and mortality from chronic illness (Sayer \& Kirkwood, 2015).

Physical activity is a very complex behaviour that can be measured in many ways. A range of instruments are available for evaluating physical activity including objective methods and those based on self-reports. These measurement tools can be used to measure both physical activity and inactivity (Miles, 2007).

Reports have described the use of various questionnaires, diaries, or logs for evaluating physical fitness level, and for monitoring body or physiological responses by using the International Physical Activity Questionnaire (IPAQ) and 
Borg's Scale, among others (Haskell \& Kiernan, 2000). One of these questionnaires is the Domain-Specific Physical Activity Efficacy Questionnaire (DSPAEQ). While the International Physical Activity Questionnaire (IPAQ) evaluates physical activity level as metabolic equivalents (METS) in single items, DSPAEQ evaluates physical activity by a domain-specific approach (ambulatory activities efficacy, household activities efficacy, leisure-time activities efficacy, transportation activities efficacy and school activities efficacy).

Using DSPAEQ can lead to different results in evaluating an individual's physical activity level. In this regard, the aim of this study is to compare physical activity efficacy between adolescent girls and boys.

\section{Material and Method}

This study was conducted in accordance with the Declaration of Helsinki.

\subsection{Participants}

219 girls (body weight: $57.50 \pm 10.44 \mathrm{~kg}$, height: $160.30 \pm 7.40 \mathrm{~cm}$, age $16.15 \pm 0.96$ years), and 145 boys (body weight: $63.45 \pm 10.10 \mathrm{~kg}$, height: $173.71 \pm 5.49 \mathrm{~cm}$, age $16.20 \pm 3.49)$, in total 364 students who are living and taking education at different high school in Manisa province of Turkey participated voluntarily for this study.

\subsection{Measuring Tools}

In determining physical activity efficacy in different activity areas of students, the Domain Specific Physical Activity Efficacy Scale (DSPAEQ) According to EFA, factor loadings of all items range from $0.405-0.924$. Also, according to the reliability analysis, the dimension "in transportation" was quite reliable while all other dimensions were highly reliable. On the other hand, the compliance values of the measurement model according to the CFA results was found as $\chi 2=559.7, \mathrm{df}=289, \chi 2 / \mathrm{df}=1.93 ; \mathrm{CFI}=0.950, \mathrm{IFI}=0.951, \mathrm{NFI}=0.903 ;$ RMSEA $=0.068$ which was developed by Campbell et al. (2016) and adapted into Turkish by Saygin et al., (2017) was used in the study. DSPAEQ consists of 5 dimensions and 26 items (at school: 6 items, during transportation: 3 items, in the house: 5 items, during leisure and recreation: 6 items, and during school trips and transportation: 6 items). The scale form consisted of two sections. The first section consisted of demographical information, and in the second section they were asked how much confidence they had in themselves in physical activities performed in five activity areas. A Likert-type 10-point scale was used for the items $(0=$ no confidence at all, and 100=complete confidence). Total average score was calculated by item answers in each area ranging from $0-100$. High scores describe a high level of physical activity efficacy.

\subsection{Data Analysis}

Statistical calculations were made using the SPSS (version 18.0) Program

Data obtained were saved in the SPSS (18.0) program. Normal distribution of the data was examined with Kolmogorov Smirnov test and skewness, kurtosis values. The values for skewness and kurtosis between -2 and +2 are considered acceptable in order to prove normal univariate distribution (George \& Mallery, 2010). The skewness and kurtosis of items in all dimension of the scale was between -2 and +2 . All sub-dimensions of the scale were seen to have shown a normal distribution in both boys and girls $(\mathrm{p}>0.05)$, so Independent Sample t test was used to compare DSPAEQ sub-dimensions in different physical activity areas of students according to gender. The significance value was accepted as $\mathrm{p}<0.05$.

\section{Findings}

Comparative scores obtained from the sub-dimensions of DSPAEQ, namely, physical activity at school, physical activity during transportation, household physical activity, leisure-time and recreational physical activity, and physical activity during school trips and transportation according to gender are presented in tables 1-5, respectively.

As indicated in Table 1, when the 1st, 2nd, 3rd, 4th, 5th and 6th items of "Physical Activity at School" sub-dimension of the domain specific physical activity efficacy scale were compared according to gender, a statistically significant difference was found in favour of boys $(\mathrm{p}<0.001)$. 
Table 1. Comparing the "physical activity at school" sub-dimension of DSPAEQ according to gender $\left(\mathrm{n}_{\text {girl }}=219\right.$, $\left.\mathrm{n}_{\text {boy }}=145\right)$

\begin{tabular}{|c|c|c|c|}
\hline Physical activity at school & Gender & Mean \pm SD & $\mathbf{p}$ \\
\hline 1. How confident are you about doing average intensity $30-\mathrm{min}$. physical & & $71.8 \pm 26.3$ & \multirow{2}{*}{$<0.00$} \\
\hline exercise or other school activities every day of the school week? & $\mathrm{B}$ & $85.8 \pm 22.6$ & \\
\hline 2. How confident are you about doing average intensity $60-\mathrm{min}$. physical $\mathrm{c}$ & $\mathrm{G}$ & $61.6 \pm 28.6$ & \multirow{2}{*}{$<0.001$} \\
\hline exercise or other school activities every day of the school week? & $\mathrm{B}$ & $80.5 \pm 26.2$ & \\
\hline 3. How confident are you about doing average intensity $120-\mathrm{min}$. physical & & $50.7 \pm 29.6$ & \multirow{2}{*}{$<0.001$} \\
\hline exercise or other school activities every day of the school week? & M & $71.7 \pm 30.2$ & \\
\hline 4. How confident are you about doing high intensity $15-\mathrm{min}$. physical & & $62.9 \pm 30.4$ & \multirow{2}{*}{$<0.001$} \\
\hline exercise or other school activities every day of the school week? & $\mathrm{B}$ & $80.3 \pm 25.9$ & \\
\hline 5. How confident are you about doing high intensity 30-min. physical & & $54.6 \pm 32.1$ & \multirow{2}{*}{$<0.001$} \\
\hline exercise or other school activities every day of the school week? & $\mathrm{B}$ & $77.2 \pm 28.4$ & \\
\hline 6. How confident are you about doing high intensity 60 -min. physical & G & $45.5 \pm 32.6$ & \multirow{2}{*}{$<0.001$} \\
\hline exercise or other school activities every day of the school week? & $\mathrm{B}$ & $64.3 \pm 32.3$ & \\
\hline
\end{tabular}

$* \mathrm{p}<0.05 \quad$ G: Girl, B: Boy:

Table 2. Comparing the "physical activity during transportation" sub-dimension of DSPAEQ according to gender $\left(\mathrm{n}_{\text {girl }}=219, \mathrm{n}_{\text {boy }}=145\right)$

\begin{tabular}{|c|c|c|c|}
\hline Physical activity during transportation & Gender & Mean \pm SD & $\mathbf{p}$ \\
\hline 7. How confident are you about riding a bicycle or running at & $\mathrm{G}$ & $77.7 \pm 27.1$ & \multirow{2}{*}{$.006^{*}$} \\
\hline a light tempo for 15 mins. on five days of the week or more? & $\mathrm{B}$ & $85.5 \pm 25.0$ & \\
\hline 8. How confident are you about riding a bicycle or running & G & $73.6 \pm 27.5$ & \multirow[b]{2}{*}{$.005^{*}$} \\
\hline $\begin{array}{l}\text { at a moderate tempo for } 15 \text { mins. on five days of the week or } \\
\text { more? }\end{array}$ & B & $81.7 \pm 26.9$ & \\
\hline 9. How confident are you about riding a bicycle or running & G & $64.2 \pm 29.1$ & \multirow[b]{2}{*}{$.001 *$} \\
\hline $\begin{array}{l}\text { at a moderate tempo for } 60 \text { mins. on five days of the week or } \\
\text { more? }\end{array}$ & B & $74.7 \pm 27.4$ & \\
\hline
\end{tabular}

*p $<0.05 \quad$ G: Girl, $\quad$ Boy: B

As indicated in Table 2, when the 7th, 8th and 9th items of the "Physical Activity during Transportation" sub-dimension of the domain specific physical activity efficacy scale were compared according to gender, a statistically significant difference was found in favour of boys ( $\mathrm{p}=0.006, \mathrm{p}=0.005$ and $\mathrm{p}=0.001$, respectively).

Table 3. Comparing the "household physical activity" sub-dimension of DSPAEQ according to gender $\left(\mathrm{n}_{\text {girl }}=219\right.$, $\left.\mathrm{n}_{\text {boy }}=145\right)$

\begin{tabular}{|c|c|c|c|}
\hline Household physical activity & Gender & Mean \pm SD & $\mathbf{p}$ \\
\hline \multirow{2}{*}{$\begin{array}{l}\text { 10. How confident are you about doing light-intensity } \\
\text { housework for } 15 \text { mins. on two days of the week or more? }\end{array}$} & G & $82.2 \pm 26.1$ & \multirow[b]{2}{*}{$.014 *$} \\
\hline & B & $74.7 \pm 31.2$ & \\
\hline \multirow{2}{*}{$\begin{array}{l}\text { 11. How confident are you about doing light-intensity } \\
\text { housework for } 30 \text { mins. on two days of the week or more? }\end{array}$} & G & $78.1 \pm 26.5$ & \multirow[b]{2}{*}{$.017 *$} \\
\hline & B & $70.8 \pm 31.7$ & \\
\hline \multirow{2}{*}{$\begin{array}{l}\text { 12. How confident are you about doing light-intensity } \\
\text { housework for } 60 \text { mins. on two days of the week or more? }\end{array}$} & $\mathrm{G}$ & $70.0 \pm 28.2$ & \multirow[b]{2}{*}{$.028^{*}$} \\
\hline & B & $62.6 \pm 34.9$ & \\
\hline \multirow{2}{*}{$\begin{array}{l}\text { 13. How confident are you about doing moderate-intensity } \\
\text { housework for } 30 \text { mins. on two days of the week or more? }\end{array}$} & $\mathrm{G}$ & $67.8 \pm 29.6$ & \multirow[b]{2}{*}{$.034 *$} \\
\hline & B & $60.7 \pm 33.2$ & \\
\hline $\begin{array}{l}\text { 14. How confident are you about doing moderate-intensity } \\
\text { housework for } 60 \text { mins. on two days of the week or more? }\end{array}$ & $\begin{array}{l}\mathrm{G} \\
\mathrm{B}\end{array}$ & $\begin{array}{l}62.2 \pm 30.7 \\
56.5 \pm 33.5\end{array}$ & .096 \\
\hline
\end{tabular}
*p $<0.05$ G: Girl, Boy: B

As indicated in Table 3, when the 10th, 11th, 12th and 13th items of the "Household/ Physical Activity" sub-dimension of the domain specific physical activity efficacy scale were compared according to gender, there was a statistically significant difference in favour of girls $(\mathrm{p}<0.05)$. However, there was no statistically significant difference according to gender for the 14th item ( $>0.05)$

As indicated in Table 4, when the 15th, 16th, 17th, 18th, 19th and 20th items of the "Leisure-time and Recreational Physical Activity" sub-dimension of the domain specific physical activity efficacy scale were compared according to gender, a statistically significant difference was found in favour of boys $(\mathrm{p}<0.001)$. 
Table 4. Comparing the "leisure-time and recreational physical activity" sub-dimension of DSPAEQ according to gender $\left(\mathrm{n}_{\mathrm{girl}}=219, \mathrm{n}_{\text {boy }}=145\right)$

\begin{tabular}{|c|c|c|c|}
\hline Leisure-time and recreational physical activity & Gender & Mean \pm SD & $\mathbf{p}$ \\
\hline $\begin{array}{l}\text { 15. How confident are you about doing these types of } \\
\text { moderate-intensity physical activities for } 30 \text { mins. for three days } \\
\text { of the week or more? }\end{array}$ & $\mathrm{B}$ & $73.3 \pm 2.5 .9$ & $<0.001$ \\
\hline $\begin{array}{l}\text { 16. How confident are you about doing these types of } \\
\text { moderate-intensity physical activities for } 60 \text { mins. for three days } \\
\text { of the week or more? }\end{array}$ & $\mathrm{G}$ & $67.2 \pm 26.2$ & $<0.001$ \\
\hline $\begin{array}{l}\text { 17. How confident are you about doing these types of } \\
\text { moderate-intensity physical activities for } 120 \text { mins. for three } \\
\text { days of the week or more? }\end{array}$ & G & $58.4 \pm 26.8$ & $<0.001$ \\
\hline $\begin{array}{l}\text { 18. How confident are you about doing these types of vigorous } \\
\text { physical activities for } 15 \text { mins. for three days of the week or } \\
\text { more? }\end{array}$ & G & $62.3 \pm 29.0$ & $<0.001$ \\
\hline $\begin{array}{l}\text { 19. How confident are you about doing these types of vigorous } \\
\text { physical activities for } 30 \text { mins. for three days of the week or } \\
\text { more? }\end{array}$ & G & $\begin{array}{l}56.5 \pm 29.0 \\
74.8 \pm 25.9\end{array}$ & $<0.001$ \\
\hline $\begin{array}{l}\text { 20. How confident are you about doing these types of vigorous } \\
\text { physical activities for } 60 \text { mins. for three days of the week or } \\
\text { more? }\end{array}$ & $\mathrm{G}$ & $\begin{array}{l}50.4 \pm 29.7 \\
68.4 \pm 29.9\end{array}$ & $<0.001$ \\
\hline
\end{tabular}

Table 5. Comparing the "physical activity during school trips and transportation" sub-dimension of DSPAEQ according to gender $\left(\mathrm{n}_{\text {girl }}=219, \mathrm{n}_{\text {boy }}=145\right)$

\begin{tabular}{|c|c|c|c|}
\hline Physical activity during school trips and transportation & Gender & Mean \pm SD & $\mathbf{p}$ \\
\hline \multirow{2}{*}{$\begin{array}{l}\text { 21. How confident are you about light- intensity walking } \\
\text { during school time for } 15 \text { mins every day of the school } \\
\text { week? }\end{array}$} & $\mathrm{G}$ & $83.8 \pm 24.8$ & \multirow[b]{2}{*}{.185} \\
\hline & B & $87.3 \pm 23.8$ & \\
\hline \multirow{2}{*}{$\begin{array}{l}\text { 22. How confident are you about light- intensity walking } \\
\text { during school time for } 30 \text { mins every day of the school } \\
\text { week? }\end{array}$} & $\mathrm{G}$ & $80.7 \pm 24.1$ & \multirow[b]{2}{*}{.178} \\
\hline & B & $84.3 \pm 26.2$ & \\
\hline \multirow{2}{*}{$\begin{array}{l}\text { 23. How confident are you about light- intensity walking } \\
\text { during school time for } 60 \text { mins every day of the school } \\
\text { week? }\end{array}$} & G & $75.9 \pm 25.5$ & \multirow[b]{2}{*}{.057} \\
\hline & B & $81.1 \pm 25.4$ & \\
\hline \multirow{2}{*}{$\begin{array}{l}\text { 24. How confident are you about light-intensity walking } \\
\text { for } 15 \text { mins. on five or more days of the week? }\end{array}$} & $\mathrm{G}$ & $81.0 \pm 25.1$ & \multirow{2}{*}{.054} \\
\hline & $\mathrm{B}$ & $86.1 \pm 24.2$ & \\
\hline \multirow{4}{*}{$\begin{array}{l}\text { 25. How confident are you about light-intensity walking } \\
\text { for } 30 \text { mins. on five or more days of the week? } \\
26 . \text { How confident are you about light-intensity walking } \\
\text { for } 60 \text { mins. on five or more days of the week? }\end{array}$} & G & $76.4 \pm 26.6$ & \multirow{2}{*}{$.005^{*}$} \\
\hline & $\mathrm{B}$ & $84.2 \pm 23.9$ & \\
\hline & $\mathrm{G}$ & $71.4 \pm 29.3$ & \multirow{2}{*}{$.023^{*}$} \\
\hline & $\mathrm{B}$ & $78.3 \pm 26.1$ & \\
\hline
\end{tabular}

$* \mathrm{p}<0.05$ G: Girl, B: Boy

As indicated in Table 5, when the 25th and 26th items of the "Physical Activity During School Trips and Transportation" sub-dimension of the domain specific physical activity efficacy scale were compared according to gender, there was a statistically significant difference in favour of boys $(\mathrm{p}=0.005$ and $\mathrm{p}=0.023$, respectively).

However, there was no statistically significant difference in the 21st, 22nd, 23rd or 24th items between girls and boys.

\section{Discussion}

Saygin (2014) reported that it is critical for public health to make children gain physical activity habits at very early ages, as well as good behaviours, to prevent obesity as early as possible. The results of the present study have shown that DSPAE scores of the boys were higher than those of the girls. Also, the main findings of this study are a) the school activity, transportation activity and leisure activity sub-dimension scores were higher in the boys than in the girls, whereas b) the household activity sub-dimension score was higher in the girls than in the boys. These results are not 
surprising, since in Turkish families girls generally help their parents in household activities. In line with the findings of the present study, Dağcı and Saygin (2015) reported a significant difference between the pedometer values of adolescent boys and girls.

In this context, Sallis et al. (1996) reported that boys have higher activity levels according to girls due to psychological, social, environmental and ethnic differences. As in the study of Sallis et al. (1996), in this study it is reported that boys are physically more active than girls. This situation is explained as boys reported taking more vigorous exercise outside school and during school physical education, as well as more participation in sports teams, but girls declared taking more activity-related lessons and classes (Sallis et al., 1996).

This study cannot explain why boys are physically more active than girls in the absence of certain variables such as income level of the family, social status of the family, participation in sports activity independently of school physical activity classes, whether or not parents of the adolescents participate in physical activity, personality characteristics of the adolescents (self-efficacy, self-confidence, motivation, etc), and access to physical activities such as the location of parks and schools (Strauss et al.,2001).

Age is not responsible for the differences in domain-specific physical activity level efficacy examined in this study, since the groups were homogeneous in terms of age. Riddoch et al (2004) reported that with regard to total activity, 9-yr-olds are considerably more active than 15 -yr-olds. We concluded from Riddoch's study that older children are more inactive than younger children.

Another important factor affecting adolescents' participation in physical activity is the support of parents (Sallis et al., 1999). Parents can be encouraged to support their teens' physical activity participation verbally or by rewarding them.

Strauss et al. (2001) reported that there was a significant decline in physical activity levels between ages 10 and 16, particularly in girls. According to Strauss et al. (2001), the most important personality factor leading to adolescent physical activity is self-efficacy. Reynolds et al. (1990) demonstrated that self-efficacy was significantly correlated with self-reported levels of physical activity in adolescents. Also, Sallis et al (1986) showed that self-efficacy was the strongest correlate of exercise behaviours in a community sample of adults.

As it can be seen, adolescents' participation in physical activity is a complex subject. Adolescents are affected by many factors such as biological and developmental factors, psychological factors, social and cultural factors, and physical environment factors when participating in physical activity (Sallis et al., 1992). Comprehensive studies with larger samples are needed for a better understanding of the participation of adolescents in physical activity.

Especially in our country, certain programs which are applied in some countries, such as school-based programs, community-based programs and family-based programs should be designed and put into practice. Turkish adolescent girls should be directed towards physical activities, especially those applied out of the house.

\section{References}

Al Snih, S., Markides, K. S., Ray, L., Ostir, G. V., \& Goodwin, J. S. (2002). Handgrip strength and mortality in older Mexican Americans. Journal of the American Geriatrics Society, 50(7), 1250-1256. https://doi.org/10.1046/j.1532-5415.2002.50312.x

Artero, E. G., Lee, D. C., Ruiz, J. R., Sui, X., Ortega, F. B., Church, T. S., ... Blair, S. N. (2011). A prospective study of muscular strength and all-cause mortality in men with hypertension. Journal of the American College of Cardiology, 57(18), 1831-1837. https://doi.org/10.1016/j.jacc.2010.12.025

Blair, S. N. (2009). Physical inactivity: the biggest public health problem of the 21 st century. British journal of sports medicine, 43(1), 1-2.

Campbell, N., Gray, C., Foley, L., Maddison, R., \& Prapavessis, H. (2016). A domain-specific approach for assessing physical activity efficacy in adolescents: From scale conception to predictive validity. Psychology of Sport and Exercise, 22, 20-26. https://doi.org/10.1016/j.psychsport.2015.05.002

Dagci, G., \& Saygin, Ö. (2015). Investigation of Physical Activity Levels and Body Compositions of Adolescent Boys and Girls. STUDIES ON ETHNO-MEDICINE, 9(3), 385-390.

Garber, C. E., Blissmer, B., Deschenes, M. R., Franklin, B. A., Lamonte, M. J., Lee, I. M., ... Swain, D. P. (2011). Quantity and quality of exercise for developing and maintaining cardiorespiratory, musculoskeletal, and neuromotor fitness in apparently healthy adults: guidance for prescribing exercise. Medicine \& Science in Sports \& Exercise, 43(7), 1334-1359. https://doi.org/10.1249/MSS.0b013e318213fefb

George, D., \& Mallery, M. (2010). SPSS for Windows Step by Step: A Simple Guide and Reference, 17.0 update (10a ed.) Boston: Pearson. 
Haskell, W. L., \& Kiernan, M. (2000). Methodologic issues in measuring physical activity and physical fitness when evaluating the role of dietary supplements for physically active people. The American journal of clinical nutrition, 72(2), 541s-550s.

King, A. C., Blair, S. N., Bild, D. E., Dishman, R. K., Dubbert, P. M., Marcus, B. H., ... Yeager, K. K. (1992). Determinants of physical activity and interventions in adults. Medicine \& Science in Sports \& Exercise. https://doi.org/10.1249/00005768-199206001-00005

Kruk, J. (2014). Health and economic costs of physical inactivity. Asian Pac J Cancer Prev, 15(18), 7499-503. https://doi.org/10.7314/APJCP.2014.15.18.7499

Miles, L. (2007). Physical activity and health. Nutrition bulletin, 32(4), 314-363. https://doi.org/10.1111/j.1467-3010.2007.00668.x

Oldridge, N. B. (2008). Economic burden of physical inactivity: healthcare costs associated with cardiovascular disease. European Journal of Cardiovascular Prevention \& Rehabilitation, 15(2), 130-139. https://doi.org/10.1097/HJR.0b013e3282f19d42

Paffenbarger Jr, R. S., Hyde, R., Wing, A. L., \& Hsieh, C. C. (1986). Physical activity, all-cause mortality, and longevity of college alumni. New England journal of medicine, 314(10), 605-613. https://doi.org/10.1056/NEJM198603063141003

Pekkanen, J., Nissinen, A., Marti, B., Tuomilehto, J., Punsar, S., \& Karvonen, M. (1987). Reduction of premature mortality by high physical activity: a 20-year follow-up of middle-aged Finnish men. The lancet, 329(8548), 1473-1477. https://doi.org/10.1016/S0140-6736(87)92218-5

Physical inactivity a leading cause of disease and disability, warns WHO. http://www.who.int/mediacentre/news/releases/release23/en/

Physical Inactivity: A Global Public Health Problem. http://www.who.int/dietphysicalactivity/factsheet_inactivity/en/

Reynolds, K. D., Killen, J. D., Bryson, S. W., Maron, D. J., Taylor, C. B., Maccoby, N., \& Farquhar, J. W. (1990). Psychosocial predictors of physical activity in adolescents. Preventive medicine, 19(5), 541-551. https://doi.org/10.1016/0091-7435(90)90052-L

Riddoch, C. J., Andersen, L. B., Wedderkopp, N., Harro, M., Klasson-Heggebo, L., Sardinha, L. B., ... Ekelund, U. L. F. (2004). Physical activity levels and patterns of 9-and 15-yr-old European children. Medicine and science in sports and exercise, 36(1), 86-92. https://doi.org/10.1249/01.MSS.0000106174.43932.92

Sallis, J. F., Prochaska, J. J., \& Taylor, W. C. (2000). A review of correlates of physical activity of children and adolescents. Medicine and science in sports and exercise, 32(5), 963-975. https://doi.org/10.1097/00005768-200005000-00014

Sallis, J. F., Zakarian, J. M., Hovell, M. F., \& Hofstetter, C. R. (1996). Ethnic, socioeconomic, and sex differences in physical activity among adolescents. Journal of clinical epidemiology,49(2), 125-134. https://doi.org/10.1016/0895-4356(95)00514-5

Sayer, A. A., \& Kirkwood, T. B. (2015). Grip strength and mortality: a biomarker of ageing? Lancet (London, England), 386(9990), 226. https://doi.org/10.1016/S0140-6736(14)62349-7

Saygin, O. (2014). Physical activity level and obesity prevalence of primary and secondary students. Anthropologist, 18(2), 371-377.

Saygın, Ö., Göral, K., Bingöl, E., \& Ceylan, H. İ. (2017). Turkish adaptation of the physical activity efficacy scale: the study of validity and reliability, International Journal of Sports, Exercise and Training Science, 3(2), 44-54. https://doi.org/10.18826/useeabd.308845

Strauss, R. S., Rodzilsky, D., Burack, G., \& Colin, M. (2001). Psychosocial correlates of physical activity in healthy children. Archives of Pediatrics \& Adolescent Medicine, 155(8), 897-902.

https://doi.org/10.1001/archpedi.155.8.897

\section{Copyrights}

Copyright for this article is retained by the author(s), with first publication rights granted to the journal.

This is an open-access article distributed under the terms and conditions of the Creative Commons Attribution license which permits unrestricted use, distribution, and reproduction in any medium, provided the original work is properly cited. 